Article

\title{
Good Status in the Changing Climate?-Climate Proofing Law on Water Management in the EU
}

\author{
Suvi-Tuuli Puharinen
}

check for updates

Citation: Puharinen, S.-T. Good Status in the Changing Climate? -Climate Proofing Law on Water Management in the EU. Sustainability 2021, 13, 517. https://doi.org/ $10.3390 /$ su13020517

Received: 17 December 2020

Accepted: 5 January 2021

Published: 7 January 2021

Publisher's Note: MDPI stays neutral with regard to jurisdictional clai$\mathrm{ms}$ in published maps and institutional affiliations.

Copyright: () 2021 by the author. Licensee MDPI, Basel, Switzerland. This article is an open access article distributed under the terms and conditions of the Creative Commons Attribution (CC BY) license (https:// creativecommons.org/licenses/by/ $4.0 /)$.
Department of Law, University of Eastern Finland, 80100 Joensuu, Finland; suvi-tuuli.puharinen@uef.fi

\begin{abstract}
Climate change impacts constitute a major risk to the attainment of water policy objectives. This article analyses the resilience of the EU Water Framework Directive (WFD) in the light of the challenges that climate change brings to achieving the Directive's objectives, no-deterioration and good status of surface waters and groundwater. The WFD includes mechanisms to adapt the water management objectives to climate change impacts, including redefining good status and application of exemptions. However, more harmonised efforts at the EU level would be needed to ensure an equal level of ambition and continuity in the water management objectives capacity to steer towards sustainable regime shifts.
\end{abstract}

Keywords: water management law; climate change; resilience of law; climate-proofing

\section{Introduction}

Climate change disrupts both environmental conditions and human societies with increasing intensity and frequency. The aspirations of the Paris Agreement under the United Nations Framework Convention on Climate Change (UNFCCC) to maintain the increase in global average temperature to well below $2{ }^{\circ} \mathrm{C}$ compared to pre-industrial temperature, preferably limited to $1.5^{\circ} \mathrm{C}$, will not be attained with the policy pledges given so far, even if they are fully implemented. The world is still on track to reach $1.5^{\circ} \mathrm{C}$ warming in the 2030s and to exceed the $2{ }^{\circ} \mathrm{C}$ threshold in the 2040s [1-3]. The world's warming pathway during the next decades means long-lasting and potentially irreversible changes in environmental conditions [4-6]. The most drastic changes will occur in aquatic ecosystems as the climate change impacts will mostly be realised through water. Furthermore, freshwater ecosystems are the most vulnerable and degraded ecosystems globally, which seriously compromises their resilience to withstand and adapt to climate change impacts [7-9].

The EU Water Framework Directive (2000/60/EC, WFD) requires implementation of an integrated water management system with the aim of preventing deterioration of Europe's inland surface waters and groundwater, achieving good ecological status (or respectfully, potential) and good chemical status in surface waters and good quantitative status and good chemical status in groundwater by 2015, a deadline which could be extended up to 2027. However, so far only a limited number of water bodies have improved in status since the Directive's implementation and there are serious concerns, particularly concerning surface waters, about whether the objectives will be realised in a substantial percentage of waters, even in the extended timeframe of 2027 [10-12].

Simultaneously, climate change will have impacts on all elements in surface water ecological status as well as groundwater quantitative status, increasing in intensity and frequency in upcoming years $[13,14]$. As good status is thought to illustrate conditions of healthy and resilient aquatic ecosystem, water bodies where good status is not reached yet are at risk of experiencing further degradation due to climate change [8,14]. Accordingly, climate change impacts risk deteriorating water status and imperiling the achievement of objectives in the Directive's deadline, even making the achievement of the objectives 
outright impossible $[8,11,13,15]$. In addition, adaptation responses such as increased water abstraction in response to agricultural irrigation needs, new flood defence infrastructure and coastal armouring in response to sea level rise, might have adverse impacts on water management objectives [14]. Hence, serious trade-off situations between societal interests and water management objectives can be expected in the future.

Thus, although the challenges climate change poses to environmental legal regimes in reaching their policy objectives have, to date, been mostly recognised in the field of biodiversity conservation law [16-18], climate change also necessitates rethinking the water quality and quantity objectives for water management laws and policies. Healthy and functioning water ecosystems offer valuable ecosystem services for climate mitigation and society's adaptation to climate change, since they can act as carbon sinks, facilitate renewable energy generation, provide drinking water and irrigation water, regulate water flows and extreme conditions and support biodiversity $[2,8,9,19]$. Thus, reaching the WFD's objectives is crucial for climate mitigation and adaptation in the water-nexus [20]. At the same time, climate change is transforming environmental baseline conditions and aggravating pressures in aquatic ecosystems, which hamper achieving the water management objectives and thus risks the water-ecosystems' ability to provide climate change mitigation and adaptation benefits that societies depend upon [2,8,9]. Hence, it is important that the regulation on water management objectives can respond to these impacts to remain operational and continue to promote sustainable water management in changing social-ecological conditions.

This article analyses the legal regime of the WFD on environmental objectives in the light of the climate change challenge. Accordingly, the article addresses the questions of how climate change impacts can be dealt with in the environmental objectives of the WFD and the implications this has on promoting sustainable water management. I call this assessment climate-proofing the law on water management objectives. The theoretical background for these research questions and approach is the adaptive law and legal resilience theory, where academic literature has established criteria for assessing and improving the resilience and adaptive capacity of legal regimes to be better equipped to govern social or environmental change such as the climate change. The analyses in this article on the regulation on the environmental objectives in the WFD allow for making conclusions on what features of the WFD's regulation on environmental objectives are strong in terms of resilience and what features could prove to be problematic.

Chapter 2 of the article presents this theoretical framework and synthesises the main elements and criteria for assessing the resilience of legal instruments established in academic literature on legal resilience and adaptive law and establishes the need to pay closer attention to the regulation of the environmental objectives. Chapter 3 analyses the regulation on the environmental objectives particularly in the light of climate change impacts and challenges. Chapter 4 provides conclusions of these analyses and discusses the resilience features of the WFD's regulation on environmental objectives and what implications these might have on building the social-ecological systems' resilience to climate change.

\section{Climate Change and Water Management Law in the EU}

\subsection{Law for Social-Ecological Resilience to Climate Change}

Social-ecological resilience is usually conceptualised in the sense of ecological resilience, that is, the ability of a social-ecological system to absorb change without shifting to a new regime with a different set of processes and structures [21,22]. Climate change presents a disturbance of an unforeseen magnitude and severity, which will seriously test the resilience of social-ecological systems. Resilience of social-ecological systems includes adaptive capacity, that is, the capacity to absorb change and disturbances and alter itself in response without shifting to a new, undesirable regime with different processes and structures. Notably, to make Europe more climate-resilient, the EU Adaptation Strategy to climate change aims to enhance the preparedness and capacity of all governance levels to respond to the impacts of climate change [23]. Yet resilience also calls for transformative 
capacity, which is the potential of a social-ecological systems to shift to a different, but still socially desirable and sustainable regime, when the previous regimes proves to be unsustainable in the face of social-ecological change [24]. In the climate context, this means societal shifts from greenhouse gas intensive economy to a low-carbon one.

There are two perspectives to the relationship between (environmental) law and climate resilience. The law for resilience perspective recognises the importance of the law in building the resilience of social-ecological systems by facilitating adaptation to climate change, providing the necessary (social) stability and triggering regime shifts to more desirable system states [25-29]. In case of the water-nexus of the climate change challenge, water management law can increase the resilience of social-ecological systems to water related risks of climate change by prompting shifts from practices and structures causing water quality and quantity degradation to more sustainable use and management. In the EU, legal instruments for promoting climate resilience in the water-nexus include the Floods Directive (2007/60/EC) and the EU Water Scarcity and Drought Strategy [30] as well as the Water Reuse Regulation (EU N:o 2020/741). However, the WFD is the most important legal framework for fostering overall management of water resources, including their sustainable use and protection.

However, in order to remain operational and effective in steering social-ecological resilience, the law itself must possess resilience features to disturbances such as climate change [29]. The resilience of legal systems perspective looks into the resilience of the legal systems themselves, assessing their capacity to remain operational and effective in the changing world [31-34]. The theoretical underpinnings of this perspective are perhaps more important for the purpose of this article.

For assessing and measuring the reliance of legal systems, an ample set of criteria has been established in the academic literature. Like the resilience of social-ecological systems, the crucial elements for the law's resilience are adaptive capacity to changes in circumstances or increased knowledge of the social-ecological system [35] (pp. 289-290), and transformative capacity to change its structures and processes towards a more sustainable regime $[29,36]$. This involves both substantive law, where the legal regime should have the capacity to alter its requirements, standards and goals in response to changed conditions, and procedural law that refers to a legal regime's agility in implementation processes of new substantive goals and standards $[29,36]$. The law might, for example, need to change its policy objectives that do not reflect the new realities where it needs to operate or forego strong res judicata of previous decisions that forms an obstacle for sustainable regime shifts. At the same time, transformative capacity refers to the law's aim to improve social-ecological systems and induce regime shifts towards better resilience pathways by creating forceful and effective measures for change and enable dealing with trade-offs and conflicts between interest and values [25,26,28,36]. For this purpose, the law needs to maintain respect for the rule of law requirements; thus, adaptivity and agility need to be counterbalanced with some rigidity and stability in both the substance and procedural aspects of the law [37] (p. 41).

\subsection{The Resilience of the WFD}

In general, the WFD includes certain strong positive resilience features. Article 4(1) provides the common policy objectives for water governance, requiring member states to take the necessary measures to prevent deterioration of all surface waters and groundwater, to achieve good ecological status or ecological potential and good chemical status of surface waters, and good quantitative status and good chemical status of groundwater, for which the Directive sets a deadline of 2015, which member states could extend up to 2027. The objectives constitute a transformative element of the Directive, the implementation of which prompts changes and regime shifts towards more sustainable water management, accompanied with an exemption regime that facilitates trade-offs between environmental aspirations and other social-economic interests. Water management objectives are to be realised through an integrated river basin management planning process, which employs a 
multilevel governance approach to water policies, and thus provides the adaptive element in the WFD's regulation. The river basin management planning approach constitutes an adaptive process that includes:

- building knowledge base on the social-ecological context (Article 5),

- formulating management objectives for the social-ecological context (Article 4),

- participation and inclusion of the public and different stakeholders (Article 14),

- compiling the measures deemed most appropriate for achieving the water management goals in the given social-ecological context (Article 11), and

- $\quad$ review and adjustment of the management in a cyclical process based on monitoring and updates of analyses (Article 9).

Thus, the river basin management process for formulating the water policies at the river basin district level entails flexibility to deal with different activities, pressures and impacts in social-ecological systems, and to promote most appropriate measures for given context [35,37] (p. 289, p. 44). The WFD's regulation is adaptive in the sense that it prescribes assessments, monitoring and public participation to inform coordinated decisionmaking and adjustments in a six-year planning cycle, which promotes the responsiveness of water policies to changing circumstances and priorities, as well as to new knowledge. To this end, the Directive allows operationalising adaptive management that has been widely advocated for building resilience in natural resources policies [32,33,38-42].

Consequently, water managers have been able to evolve management plans in response to pressures and environmental effects that have not been explicitly addressed in the Directive itself, including climate change impacts such as droughts and periods of water scarcity [29] (p. 19900). The river basin management process enables identifying and addressing different climate change impacts, and regional or local social-ecological conditions, as well as formulating appropriate policy instruments based on these characteristics, and the involvement of the public and stakeholders. Member states may even opt for measures that anticipate and mitigate future impacts when the analysis, monitoring and information gained from multistakeholder involvement delivers a sufficient knowledge-base for this [37,43]. Accordingly, the Directive's fitness check in 2019, this found that the WFD is sufficiently prescriptive with regard to the pressures to be addressed, and yet flexible enough to reinforce its implementation as necessary with regard to climate change [44].

The WFD does not seek to harmonise all aspects of water policies in the member states but provides flexibility to member states on the implementation rules and procedural conditions for its objectives in different policy fields [45-47]. Hence, many resilience elements of water law, such as adaptivity of legal instruments, transformative capacity in implementation rules and processes and enforcement mechanism, depend on the design of national laws that regulate operations, sectors and administrative processes that control the impacts, pressures and protection of waters. However, this is not the whole picture because the WFD also contains some rather prescriptive implementation rules and instruments. Article 11 provides that water management measures are harmonised to the extent of measures deriving from relevant EU legislation that contains prescriptive instruments and rules, including measures required under the Nitrates Directive (91/676/EEC), Industrial Emissions Directive (2010/75/EU) and Urban Wastewater Directive (91/271/EEC). In addition, Article 11 requires establishing certain specific legal instruments for water management, including mandatory permitting requirements for a vast group of activities such as water abstraction, impoundment, artificial recharge of groundwater, point source discharges and any other activities causing significant adverse impacts to water, particularly to hydromorphological conditions (Article 11(3) paras e-i).

Furthermore, the environmental objectives provided in Article 4 of the WFD constitute rather strict and enforceable rules both for individual water management measures such as permitting and for the member states water management policies in their entirety. Article 4 (1) requires member states to take the necessary measures to prevent deterioration and achieve good status in making operational the programmes of measures. This means that the environmental objectives provide the substantive outcome for implementation of the 
water management measures, that is, measures deriving from other EU law, permit controls required under the WFD and the national water policy measures and instruments included in the programmes of measures by national water managers.

The Court of Justice of the European Union (CJEU) has confirmed that the environmental objectives of no deterioration and achieving good status constitute binding rules on the permitting processes that are important water management measures in the implementation of water management objectives. Member states may not grant a permit based on their national laws for projects that would cause deterioration in the water status or that would jeopardise the achievement of good status, unless an exemption provided in Article 4(7) of the WFD applies [48,49]. The interpretation of deterioration is strict, encompassing deterioration of even one quality element used in the ecological status assessment. Furthermore, the CJEU has established that Article 4 entails rights for the individuals and environmental NGOs to challenge the legality of decisions made under national water policy laws based on the requirements deriving from Article 4 of the WFD $[49,50]$.

Accordingly, the environmental objectives and the no deterioration rule have evolved in the CJEU's case-law towards more formalistic legal rules, as they now form strict legal requirements dictating the permissibility of activities that affect water resources. Moreover, the objectives under Article 4 have been increasingly regarded to constitute binding obligations towards member states in relation to the result to be achieved, which would make achieving good status in the timeframe provided in the Directive enforceable in terms of result to be achieved towards member states [51] (pp. 522-526). This means that member states should implement the Directive in the context of their national (water) laws in a way that prompts the necessary actions to ensure that the water bodies will not deteriorate, and that they reach good status in the Directive's timeframe. Notably, the Directive includes an exemption regime that provides the conditions where member states can aim to different substantive outcomes with their water management policies. Thus, the adaptive and transformative capacity of substantive water law in the EU depends on the regulation of environmental objectives and the exemption regime in the WFD. The next chapter will analyse the capacity of the regulation on the environmental objectives and exemptions to respond to the climate change challenges.

\section{Water Management Objectives and the Changing Climate}

\subsection{What Is Good Status?-Defining the Policy Objectives}

In the WFD, the objective-setting for surface waters relates to ecosystem health and functioning (ecological status) and chemical composition (chemical status), whereas for groundwater, the objectives concern water quantity (quantitative status) and chemical composition of groundwater (chemical status). While chemical status objectives are established based on the concentrations of certain harmful chemical compounds in the water under the EU EQS Directive (2008/105(EC) and Groundwater Directive (2006/118/EC), both the ecological status and quantitative status objectives are formulated in a rather open and flexible terms in the WFD.

Surface waters are distinguished based on water body categories and types, for which the Directive provides a five-level classification system for their ecological status. Annex $\mathrm{V}$ to the WFD provides normative descriptions for the ecological status quality elements (biological, physio-chemical and hydro-morphological conditions) in each status class that are based on deviance from the reference conditions for ecological status, high status (Annex $\mathrm{V}$ to the WFD, Section 1.2). For the groundwater quantitative status objective, the WFD only provides general definitions for good quantitative status, while more specific formulation is left to water managers (Annex V, Section 2.1). Both ecological status and quantitative status objectives need to be elaborated into more specific objectives in river basin management planning, which allows formulating the objectives to fit the environmental conditions in the river basin management district $[52,53]$. However, to decrease the flexibility in determining the ecological status objectives, descriptions of good ecological status and the reference conditions for each surface water type are harmonised for geographical regions with the 
so-called intercalibration exercise, and formalised in a binding commission decision (WFD Annex V, Section 1.4.1, Commission Decision 2013/480/EU).

In addition to differences in the flexibility for setting the specific objectives, the focus of good ecological status and good quantitative status differ. Good ecological status means only a slight deviation from the benchmark for ecological status assessment, high status, which illustrates the state of the water body with no or very low human impact (WFD Annex V, Section 1.2) [54]. Therefore, in good ecological status there can only be low levels of distortion from human activities, which means that social and economic interests in the social-ecological system are primarily reflected in the water management objectives via the WFD's exemption regime or designation of artificial or heavily modified water bodies (WFD Annex V, Section 1.2.5). Contrarily, good quantitative status of groundwater is defined as a sustainable balance of groundwater abstraction and generation of water, illustrating long-term sustainability of the water resource use and functioning of the groundwater body in terms of the ecosystem services it provides (Article 2(26) of the WFD, Annex V, Section 2.1.2). At the outset, the quantitative status objectives represent a more multifaced goal than the ecological status objective, which aims for almost a pristine, historical state of waters with minimized human impact.

However, the reliance of the WFD's objectives on pristine, historic conditions of water bodies, and the unrealistic expectations of reversing human impacts, is far from compatible with the realities of ecosystem functioning and an unsustainable starting point for a legal framework in the face of climate change. The feasibility and sustainability of substantive law that seeks to maintain status quo of ecosystems, or to restore them to any historical state prior to anthropogenic pressures, has been contested by the notion of the complex-adaptive features of the ecosystems that has shown that there is no inherent equilibrium state of ecosystems, and that altered systems do not spontaneously return to normal when pressures stop $[29,55,56]$. Climate change triggers several impacts on management, including: (1) changing environmental conditions; (2) the exacerbated effects of existing pressures [8] (pp. 39-42) and (3) new pressures from mitigation and adaptation responses [57] (p. 63). Thus, climate change will inevitably and irreversibly alter natural conditions and the social-economic context, rendering attainment of any stable, pristine or historical state of aquatic ecosystems extremely challenging and most likely impossible, because of both ecological and socio-economic realities [31-33,35] (pp. 59-63, 32-40, 391-395, 289). In addition, these effects are categorised with a high level of uncertainty, because climate trajectories, magnitude and rate of the warming, direct impacts on ecosystems and societies, and long-term implications are widely unknown [58].

Accordingly, an important part of building resilient legal frameworks is to reassess and adjust the policy objectives and related substantive law so that the policies are going in the right direction. There are two prominent approaches to climate resilient environmental policy objectives, the resilience-focused approach and the shifting baselines approach. The resilience-focused approach boils down to modifying resource-specific management goals to focus on, for example, key ecosystem functions or key ecosystem services rather than maintaining specific characteristic such as specific flow regimes, species distribution or chemical composition [59]. In contrast, the shifting baselines approach refers to reflecting the new environmental realities caused by climate change in the reference points for environmental policy objectives; environmental law may still strive for good water status, but the content of these objectives is adapted [33] (p. 38). The next chapter will analyse the capacity of the WFD's regulation on the environmental objectives and exemptions to deal with climate change impacts and aims to recognise if these approaches to climate resilient policy objectives could be implemented in the WFD's framework.

\subsection{Changing Natural Conditions}

Climate change causes wide-ranging impacts on both surface waters and groundwater that will increase in both intensity and frequency in upcoming years, thus affecting the possibilities to reach the WFD's objectives during the next decade [8] (pp. 98-109, 176). 
Climate change will increase the magnitude and frequency of flooding in northern Europe, and droughts and water scarcity in southern Europe [60]. In addition, climate change will trigger changes in the baseline conditions of water ecosystems. Surface waters may experience changes to their physiochemical conditions due to increased temperature, nutrient content and concentrations of contaminants, in biological quality due to alterations in the distribution, composition and abundance ratios of species, and in their hydromorphology based on water scarcity threats to minimum water flows to sustain ecological status $[7,15]$. For groundwater, water scarcity and droughts will stress both the quality and quantity of groundwater resources, and sea level rise may result in increased saltwater intrusion into groundwaters in coastal areas [14,15] (pp. 26-27, 123-125).

While these effects affect the possibilities of reaching good status, particularly how it is defined for surface waters in the WFD, water bodies that are currently in a lower status than good, and that are thus more vulnerable to disturbances, are also at risk of experiencing further degradation due to climate change [8,14] (pp. 9, 98-109). For the purpose of conceptualising climate change impacts in natural conditions with regard to the WFD's objectives, they can be divided into: (i) immediate but temporal impacts from extreme weather conditions (e.g., droughts and floods and associated impacts); (ii) gradually evolving and enduring deterioration due to changing ecosystem conditions and (iii) changing ecosystem conditions that jeopardise or hinder the achievement of the good status objectives [13] (p. 1049).

The first group of impact (extreme weather conditions such as floods and droughts) may trigger increased application of Article 4(6) of the WFD. Article 4(6) allows for temporarily exempting from the no deterioration rule in the case of extreme events like circumstances of natural cause or force majeure such as accidents that are exceptional and that could not reasonably have been foreseen. Thus, this exemption is applicable to floods or droughts that deteriorate water status and the immediate responses taken to mitigate them. Application of Article 4(6) presupposes that further deterioration is prevented to the extent practicable, that measures do not compromise the recovery of the water body once the circumstances are over, and that all practical measures are taken with the aim of restoring the water body to the status prior to the effects of the circumstances (Article 4(6) paragraphs (a), (c) and (d)). However, as it is well known that climate change will make these extreme weather events occur more frequently in the future, the question is whether these circumstances can be considered exceptional or not reasonably foreseeable [14] (p. 58). Water managers should, rather, prepare for the increased frequency of these phenomena by improving flood risk management and introducing water management measures that improve the resilience of water bodies towards extreme flooding or droughts, than rely on just applying Article 4(6) exemption when these impacts take place.

It is significantly harder to deal with the second group of impacts under the WFD, that is, water quality degradation that does not relate to extreme weather conditions but to (irreversible) changes in ecosystem conditions. The WFD includes a strict no deterioration rule, which obliges member states to prevent any deterioration in water status in cases where the water body is subject to application of exemptions under Article 4(4) or 4(5), which relate to the timeframe for achieving good status, or the level of ambition of the objectives. The no deterioration rule is a separate obligation from achieving good status, and although the Directive includes exemptions from achievement of good status based on natural conditions, it does not contain an applicable exemption for deterioration caused by changing natural conditions. To date, the approach taken to this problem under the Common Implementation Strategy (CIS) framework for established for coordinating the implementation of the WFD in member states has been to encourage the member states to rigorously predict, model and monitor the climate change impacts and adjust the plans and measures continuously to preserve the status quo in the water bodies [14]. However, this guidance omits that the Earth's warming pathway has reached a stage where even the most ambitious climate change mitigation efforts can't prevent all of its impacts, which, in turn, cannot be mitigated with water protection measures [43] (p. 723). 
Thus, it is an unsustainable starting point for water management law to oblige member states to prevent all deterioration resulting from climate change impacts. However, it should be noted that the CJEU has left open a possibility that member states could be excused from not fulfilling the obligations arising from the EU law in cases where it would be materially impossible [51] (p. 515). Although the court has to date never accepted arguments on absolute material impossibility, climate change constitutes circumstances of such unprecedented and compelling nature that the court is likely to be forced to take a stance on this issue. However, although formally neither correcting the reference conditions nor the application of Article 4(5) should be used to excuse deterioration of water status, in reality deterioration that cannot be prevented with water management measures would most likely be taken into account as a factor to justify revisiting the reference conditions or constituting conditions where reaching good status is unfeasible or disproportionately expensive within the meaning of Article 4(5).

Dealing with the third group of climate change impacts under the WFD depends on whether they are considered as anthropogenic pressures or as natural conditions. To date, climate change impacts have been regarded as pressures in water management [44], which means that measures need to be implemented to mitigate these pressures in order to achieve good status, unless a failure to do so is justified based on the WFD's exemptions. The original deadline of 2015 could be extended up to 2027 based on Article 4(4), when extension could be justified based on technical (un)feasibility or disproportionate costs associated with measures needed to bring the water body to good status, or on natural conditions prevailing in the water body. Article 4(4) does not excuse member states from taking all necessary measures to bring water bodies to good status, but provides a possibility to take technical, economic and ecological considerations into account to make the timeframe for the implementation of measures more reasonable.

However, after 2027 further extension is only possible based on natural conditions, which means that anthropogenic pressures should be dealt with by measures implemented, at the latest, during the river basin management cycle of 2021-2027, after which more time can be allowed for the measures to take effect and the ecosystem to heal. Considering climate change as an anthropogenic pressure, rather than a natural condition, would mean that member states are obligated to take all the necessary measures to mitigate its impacts, at the latest, during the management cycle of 2021-2027, after which they can only wait until the natural processes occurring in the water body eventually result in good status being achieved. In case a water body is failing to achieve good status in 2027 due to pressures that have not been sufficiently addressed with measures, the only option for member states is to set less stringent environmental objectives in accordance with Article 4(5) based on unfeasibility of measures due to technical or other reasons, disproportionate costs or natural conditions in the water body.

This is not a sustainable, nor a realistic strategy for water management policies. First, neither climate change nor its impacts can be prevented with water management measures and, second, as the impacts of climate change only begin to be realised in the 2020s, and as we will likely face the warming of $1.5^{\circ} \mathrm{C}$ or $2^{\circ} \mathrm{C}$ sometime between 2030 to 2050, it is clear that a timeframe of 2021-2027 is not sufficient for taking measures to mitigate climate change impacts jeopardising the achievement of good status. Accordingly, considering climate change as a pressure under the WFD would unlikely result in prevention of any impacts but just excessive application of Article 4(5). A more fruitful approach would, perhaps, be to take climate change into account as a natural phenomenon that sets the new environmental baselines, since climate change cannot be mitigated with water management measures. This would require adapting the definition of good status and the reference points to reflect the new environmental realities [13,61] (pp. 1046, 36-37), which implies sifting baselines approach to environmental objectives in the face of climate change. Furthermore, it has been recognised that climate change may even impact surface water typology, as a number of descriptors used in typology are climate sensitive and, therefore, water bodies could, in theory, migrate from one type to another [13,14] (pp. 1048, 52). 
In terms of groundwater quantitative status, good status means a balance between water abstraction and available groundwater resources, which is a flexible standard whose specific content is formulated in the river basin management planning process. Thus, groundwater quantitative status objective can be adaptive to changes in environmental conditions, such as climate change impacts. Good status can be achieved also in regions where groundwater formation is decreased due to changes in precipitation, water scarcity and droughts, when water abstraction is, in turn, decreased to maintain or achieve a sustainable balance in a way that other preconditions for good status are still fulfilled (WFD Annex V, Section 2.1.2). However, at the same time, the adaptation needs in societies may necessitate increasing water abstraction, which may require exemption from the quantitative status objective (see Section 3.4 of the article).

Adapting surface water ecological status to climate change impacts is more challenging because the specific definitions for high status and good status have been harmonised based on water body typology in the intercalibration process. However, characterisation of water bodies is an iterative process that can be revisited in the assessment of water body characteristics under Article 5 of the WFD, and hence, a water body could be changed to another type in the management process if the information gained during the implementation shows that climate change has resulted in such severe changes in the baseline conditions. This would, in turn, impact the objectives that are supposed to be reached in the water body. Yet this might not be sufficient to deal with all the changes taking place in the water bodies because type-specific reference points are still based on a historical, pristine, stable state of the waters, which will likely be unfeasible. It has been acknowledged, also, under the CIS, that climate change might trigger needs to correct reference conditions to accommodate ecosystem changes, which can be done in the water management process, even when this means contradicting the intercalibrated classification values if there is convincing scientific evidence, vigorous monitoring and modelling to support it [14] (p. 54).

In cases where reference conditions and definition of good status cannot be adapted, climate change impacts could, perhaps, still be considered natural conditions within the meaning of Article 4(4) that would allow further postponing the deadline for achieving good status beyond 2027. However, postponing the deadline for achieving good status based on natural conditions covers delays in nature's response to the measures taken, and the water bodies are still expected to recover and reach good status during the following management cycles [62] (p. 1235). This might not be compatible with climate change impacts, since the rate of warming and the magnitude of impacts will still accelerate after 2027, which makes it unlikely that water bodies impacted by climate change would begin to recover at any time. Therefore, these impacts should, rather, be considered natural conditions preventing the water body from reaching good status, which fall under Article 4(5), that can be applied to set less stringent environmental objectives that reflect the status whose achievement is feasible in the changing ecological realities.

\subsection{Increased Pressures and Ecosystem Vulnerability}

Climate change is predicted to exacerbate many pressures affecting water bodies such as contaminant and nutrient pollution due to increased runoff [14,43] (pp. 26-27, 723). In these cases, the existing water protection measures might not be enough in the future to mitigate the impacts of pressures in water status [61] pp. (36-37). In addition, the pressures and climate change impacts are interlinked; pressures make ecosystems more vulnerable to climate change impacts, and climate change impacts make them more vulnerable to other pressures $[13,14,61]$. This means that tackling anthropogenic pressures will be even more important in order to mitigate the most severe effects of climate change in the water bodies but, at the same time, it will require significantly more efforts in water management [33] (pp. 45, 71).

Under the WFD, the impacts that climate change has on the type and magnitude of other pressures are to be considered as anthropogenic pressures, not natural background conditions, which means that the starting point in water management is to mitigate them in 
order to prevent deterioration and allow the water bodies to reach good status [43] (p. 723). However, the measures needed to bring about the necessary improvements in water status may become significantly more expensive, challenging and even unfeasible for technical reasons [14] (p. 58). In these cases, water managers may apply Article 4(4) to postpone the deadline for achieving good status up to 2027, or by setting less stringent environmental objectives in accordance with Article 4(5) to reflect the level that can be achieved with measures that are feasible without entailing disproportionate costs.

However, the precondition for applying Article 4(5,) based on the impacts of human activities, requires that the environmental and socioeconomic needs served by such human activity cannot be achieved by other means, which are significantly better environmental options. This necessitates that the application of Article 4(5) in response to pressures from important human activity requires a case-by-case analysis on the possibilities to reduce the harmful environmental impacts of the activity in question. Thus, the challenges that climate change may pose to mitigating pressures cannot be used as a general justification to wide-range application of Article 4(5) and lowering the environmental ambition level but requires a case-by-case analysis on the opportunities to mitigate adverse effects, or even replacing the activity with an environmentally better alternative.

Exacerbated impacts that climate change has on pressures and the vulnerability of water bodies, may also risk causing deterioration in water status. The only exemptions from the no deterioration principle in the WFD are Article 4(6) for temporary deterioration from unexpected, force majeure circumstances, and Article 4(7) concerning new sustainable development projects. Neither one of these exemptions can be applied to justify deterioration resulting from increased existing pressures or increased impacts of pressures. This means that the starting point for dealing with these impacts under the WFD is to increase efforts in water management to vigorously prevent any deterioration. If this proves to be impossible, member states may attempt to justify not fulfilling their obligation to prevent deterioration of water status by arguing absolute material impossibility in accordance with the CJEU's doctrine [51] (p. 515). However, the court has so far never accepted arguments on absolute material impossibility, and the prospects of succeeding with this approach will most likely not be promising if the member states cannot demonstrate that they have done everything virtually possible to mitigate the impacts from the pressure. Yet, although formally the application of Article 4(5) should not be used to excuse this kind of deterioration of water status, in reality member states would most likely consider deterioration resulting from increased pressures or ecosystem vulnerability that is caused by the climate change as conditions where reaching good status is unfeasible or disproportionately expensive within the meaning of Article 4(5), rather than attempting to argue absolute material impossibility in fulfilling their obligations under the WFD.

\subsection{New Mitigation and Adaptation Responses}

Climate change, and its accelerating impacts on the environment, will also generate increasing needs for mitigation and adaptation efforts in social-ecological systems, which may themselves constitute new pressures on water bodies. Mitigation actions such as hydropower generation, offshore wind farms located in coastal waters and intensified energy crop production, may have adverse impacts on water status, but the EU's renewable energy production targets in Directive (EU 2018/2991) call for maintaining, or even increasing, these forms of energy production. This might complicate implementing water protection measures that, for example, would decrease the production potential from existing hydropower installations, even though restoring ecological flows and dealing with other adverse impacts of hydropower are crucial for meeting the WFD's objectives in many European rivers. Various adaptation responses also might have adverse impacts on achieving water management objectives. These include direct adaptation responses to climate change impacts such as increased water abstraction in response to agricultural irrigation needs, new flood defence infrastructure and coastal armouring in response to sea level rise [14] (pp. 49-50, 66), but also other actions related to transition to low carbon 
societies such as mining for raw materials needed for batteries. Accordingly, there will be trade-offs between climate change mitigation and adaptation actions and environmental protection that the water management law should be capable of facilitating and adapting to.

In cases of sudden natural phenomena such as flooding and droughts, member states may justify deterioration that results from ad hoc adaptation responses under Article $4(6)$ of the WFD. In the case of more planned mitigation and adaptation measures and developments, it follows from the CJEU's case-law that member states may not authorise new projects that would result in deterioration of water status, or jeopardise achievement of good status in the Directive's timeframe, without an appropriate exemption [48,49]. Accordingly, implementation of some other climate change mitigation or adaptation responses might invoke the need for an exemption under Article 4(7) [14] (p. 90). Article 4(7) allows member states to apply an exemption from the no deterioration rule, or from achieving good status, based on new modifications or sustainable development activities of overriding public interest.

The applicability of Article 4(7) is broader for physical modifications than for polluting activities. Any modification of a surface water body's physical characteristics, or alterations of groundwater level, may be subject to the exemption, whereas for other impacts the exemption only applies to deterioration from high to good status. The exemption is, therefore, applicable to some crucial adaptation measures to climate change such as water abstraction projects for irrigation needs in agriculture, new flood defence infrastructure, hydropower installations or even the diversion of a river $[63,64]$. However, for water status deterioration or failures to achieve good status that are caused by other pressures, such as pollution, for example from mining activities, the exemption is. for the most part, not applicable because the number of water bodies in high status at the European level is low.

Prerequisites for application of Article 4(7) include that all practicable steps are taken to mitigate adverse environmental impacts, and that the benefits the activity serves cannot be achieved by other, environmentally better means (Article 4(7), paras (a) and (d)). In addition, Article 4(7) requires weighing of interests between achieving water management objectives and implementation of the new project. Exemption can only be applied to activities of overriding public interest, or if the benefits of the project to human health, safety or sustainable development would outweigh the benefits of achieving the environmental objectives of the WFD.

According to the CJEU, member states have a margin of discretion in determining whether a project is of overriding public interest within the meaning of Article 4(7). In case C-346/14, recognising the promotion of renewable energy sources as a high priority of the EU, the court held that a member state could consider a hydropower plant that only marginally contributed to climate change mitigation, with moderate generation of renewable energy, a project of overriding public interest [64]. However, taking into account the importance given to the protection to water bodies in the WFD and the various other benefits that healthy and functioning water ecosystems serve, it is not evident that allowing an exemption based on overriding public interest to a hydropower project of such minimal significance to climate change mitigation is a sustainable trade-off between interests in the climate-water-nexus. In any case, the CJEU's judgement emphasises the member states' discretion in determining what constitutes an overriding public interest in the context of their water management.

However, in order for climate change mitigation or adaptation measures to be subject to application of Article 4(7) of the WFD, it has to be demonstrated that the measures contribute to safeguarding human health and safety, sustainable development or environmental protection, and that the possibilities of implementing other environmentally better options are ruled out. The prerequisites for an exemption under Article 4(7) should, therefore, ascertain that water protection aspects are reflected in design and implementation of mitigation and adaptation responses. Furthermore, the exemption and the water management objectives for the affected water body need to be reviewed every six years in the updates of the RBMP (Article 4(7), para (b)), which enables adapting the decisions on 
exemptions, e.g., in a situation where new knowledge or changes in circumstances provide opportunities to further mitigate the adverse effects of these developments.

\section{Discussion}

Climate change will bring about a multitude of changes to social-ecological systems that can disrupt the implementation and effectiveness of existing environmental statutes. Central resilience features of environmental laws relate to promoting both adaptive and transformative capacity of the legal frameworks, which entail that the law is capable of adapting to changes and changing itself, for example, by creating new substantive rules to adapt to changing conditions or to transform its goals so that they reflect transformed social-ecological systems $[29,65]$. The law's capacity to promote resilience in the socialecological systems also depends on the strength of the implementation and enforcement mechanisms and rules, through which the transformed goals and substantive rules can steer the behaviour of different actors and prompt sustainable regime shifts [37] (p. 41). Dealing with the climate change impacts, that is, the changing natural conditions, increased pressures and ecosystem vulnerability and new mitigation and adaptation responses, necessitate that the substantive law:

(1) is adaptive to changing conditions in the social-ecological system and increasing knowledge, yet

(2) maintains forceful and enforceable implementation of substantive norms that direct towards better environmental outcomes; and

(3) facilitates reconciliation of multiple environmental protection, climate change mitigation and adaptation and other societal interests and, when not mutually compatible, trade-offs between these interests.

In the WFD, climate change impacts can be reflected in water management policies by adopting a climate-sensitive approach to planning river basin management in the six-year cycles. The updates of the analyses on the characteristics of the water bodies, impacts of human activity and economic analysis on water use, can be focuses to identifying potential and expected climate impacts on water bodies and watershed functions, including society's adaptation needs. Monitoring programs can be formulated to increase monitoring for climate-sensitive water bodies to gain more information on climate change impacts in different types of water bodies in the geographical region. The programmes of measures can be climate-proofed, meaning that preventive and mitigation measures are put in place for the identified impacts, more efforts are put in place to protect and restore the resilience and health of waterbodies, and attention can be paid to regional or national adaptation strategies. The implementation and enforcement of water management has been strengthened in recent years with the CJEU's and the commission's stances, establishing a more formalistic and legally binding regime concerning the core substantive provisions of the Directive, the obligations to prevent deterioration and achieve good status. The WFD also includes mechanisms to adapt its objectives to changing circumstances, mainly in the form of exemptions but also by adapting the reference conditions for the objectives.

The Directive enables dealing with the changing natural conditions associated with climate change in the objectives by application of exemptions under Article 4(4) and 4(5), or by correcting the reference points for objectives to reflect the new baseline conditions. There are, however, certain problems with dealing with these impacts with the exemptions. Firstly, extending the deadline for reaching good status based on Article 4(4) does not reflect the situation in reality, because climate change is not a natural disturbance that would pass, or a characteristic of a water body that makes returning to the previous state slower, but a new, global, irreversible condition that makes aquatic ecosystems reorganise in a different way. Secondly, crafting less stringent objectives for each water body individually may not be efficient and may risk that the environmental protection level will become even more differentiated between member states, and even river basin districts, because neither the Directive nor the CIS framework currently provide sufficiently detailed, harmonised 
rules that would ascertain that the less stringent environmental objectives are set in a similar way.

Accordingly, it might be more appropriate to address climate change impacts on ecosystem baseline conditions as natural scientific facts with mechanisms that do not consider any social-economic aspects. The Directive also allows for correcting the reference points in the course of the RBMP process. In other words, it enables adopting a shifting baselines approach to water management objectives [33] (p. 38). The positive elements of this approach are that, unlike the resilience approach to regulatory objectives that risks enacting goals that are too broad and vague to be effectively enforced [31,66] (p. 78), management objectives be set to clearly reflect the desired ecosystem conditions, such as good water status. However, in the shifting baselines approach it may be difficult to recognise the changes induced solely by climate change in ecosystems that are affected by multiple pressures, which could lead to over-exhaustion of the climate change excuse to justify degradation resulting from anthropogenic pressures [31,67] (pp. 72-73, 1174). It is also questionable whether this approach entails sufficient incentives to mitigate ecosystem degradation that is prompted by climate change. Therefore, the most viable option could be combining both approaches by adopting specific goals that can be adapted to new environmental realities and that emphasize the features that maintain the resilience of ecosystems. Moreover, shifting baselines should only be allowed when there is clear and convincing evidence that changes are, in fact, attributable to climate change [31] (p. 82).

When it comes exacerbated effects of existing pressures or exacerbated impacts these pressures have on water status that is more vulnerable due to the stress from climate change impacts, the Directive's regulation on environmental objectives can only partly address these issues. In principle, if these impacts risk making achievement of good status unfeasible, they can be addressed with application of Article 4(5), but the Directive does not contain appropriate exemptions for dealing with deteriorations resulting from these impacts. However, Article 4(5) is applicable when achieving good status is unfeasible or disproportionately expensive for any reason, including any reason prompted by climate change, and thus it can be applied to deal with many of the climate change impacts.

However, adapting the WFD's objectives to climate change impacts based on application of Article 4(5) may lack clear, forceful rules to steer member states into improving the state of their waters. Application of Article 4(5) necessitates that regarding surface waters, the highest ecological and chemical status possible, and regarding groundwater, the least possible changes to good groundwater status, are achieved (Article 4(5), sub-paragraph (b)). Applying Article 4(5) on climate change impacts is not an excuse to not address other pressures affecting water status, but even when the level of ambition of the objectives is adjusted to what is feasible in terms of the climate change impacts, member states are still required to carry on addressing other pressures to improve water status. However, because there is no harmonised rules in the Directive, or guidance under the CIS framework on how the less stringent environmental objectives should be set, member states are free to determine the feasible level for environmental objectives themselves, which can enable less legitimate considerations to creep in and thus jeopardise the ambition level from the environmental protection perspective [11,44].

Furthermore, when the water body is subject to less stringent environmental objectives, there is limited incentive for the member state to aim to improve water status in the longer time frame. Although less stringent environmental objectives need to be reviewed in the updates of the RBMPs, application of Article 4(5) does not justify deviating from the deadline for achieving environmental objectives. In order to be in compliance with the Directive in 2027 with water bodies that have not reached good status, less stringent objectives should be set at the status quo unless improvements in the status are expected due to natural processes (in which case the water body may be subject to application of Article 4(4)). Accordingly, it might be challenging to obligate member states to commit to taking additional measures in the longer time frame beyond 2027, because the less stringent objective is already achieved. However, fostering climate resilience and adaptation 
to climate change risks in social-ecological systems needs water management law that steers towards improving water status and the health and functioning of water bodies for maintaining and improving vital ecosystem services [20].

Lastly, the WFD is responsive to dealing with new pressures from climate change mitigation and adaptation responses in a way that allows for reconciliation of different interests and fosters making trade-offs between climate change policy objectives and water management objectives. The legal strength given to the water management objectives in CJEU's case-law makes them powerful criteria for planning, permitting and implementing climate change mitigation and adaptation responses. Yet Article 4(7) allows realising mitigation and adaptation developments when their benefits are deemed to outweigh the benefits resulting from preventing deterioration, or from achieving good water status (Article 4(7), sub-paragraph (c)). However, also here there is a risk that the flexibility that the WFD entails may result in member states overusing the exemptions and compromising the achievement of water management objectives based on not-so-legitimate reasons. Thus, it could be worth considering possibilities to develop specific guidance for reconciliation of climate change mitigation and adaptation interests and the water policy objectives based on Article 4(7), highlighting that climate change mitigation and adaptation benefits that water bodies in good status provide are to be taken into consideration when comparing the benefits of a new development project.

\section{Conclusions}

To conclude, the WFD has some strong resilience features in the face of the climate change, including a flexible, adaptive and inclusive river basin management process, and adaptive goals that are enforceable towards the management outcome in its entirety and individual actors through permitting processes. Among the EU environmental regimes, the Directive is, perhaps, not most urgently in need of climate adaptation, as it can already deal with many climate change impacts by adapting its goals and management programs. However, there are also some weak points in the WFD's regulation on environmental objectives. Firstly, although the objectives can be adapted to many climate change impacts, this does not hold true for impacts that may cause deterioration of water status. Secondly, there is uncertainty about how ambitious and assertive the adapted objectives are towards more sustainable water management and safeguarding the resilience of aquatic ecosystems.

The central weaknesses in terms of the resilience of the WFD's substantive law, the water management objectives, is the reliance on pristine, historic ecosystem conditions in the ecological status objectives. While the WFD's exemption regime offers mechanism to adapt and refocus the objectives, the background notion is that ecosystems should be capable of resisting changes from anthropogenic or climate pressures, or at least return to the state prior to disturbance once the disturbance is over (see Article 4(6) and 4(4)). This is a questionable starting point for water management policies because, even without climate change, there is constant change taking place in water ecosystems, whose nonlinearity makes it unfeasible to return them to any prior state after disturbance [52,56,61] (pp. 25-28; 568-581; 32-41). Therefore, although the WFD makes an ambitious attempt to define and construct desired ecosystem conditions and management toward realizing them, in many ways the Directive's core substantive regulations and mechanisms fails to accommodate the modern understanding of social-ecological systems and their management, therefore risking the effectiveness of the Directive in terms of achieving its primary objectives. This is approach is increasingly problematic with the changing climate as the Earth is inevitably on track to unprecedented environmental change, potentially massive both in scale and magnitude. The climate change challenge can make these misguided assumptions behind the legal norms visible, and result in real problems in the implementation of water management policies and water laws.

Ecology-oriented goals accompanied with a flexible exemption regime also have the effect that instead of fostering a sustainable balance between ecological and social factors in the social-ecological systems, these factors are in a trade-off situation where a broad 
interpretation of the exemptions could water down the ecological aspirations, while a narrow interpretation could be harmful for achieving social and economic goals [68] (p. 33).

Currently, it can be predicted that the adaptation to climate change impacts in the water management policies will vary between member states in terms of considerations of climate change in river basin management plans, the use of mechanisms to adapt the goals and the level of ambition that the water management objectives have after they are adapted to climate change impacts. Member states might want to adjust the reference conditions for surface water ecological status and, without a harmonised effort like the intercalibration exercise, the ambition of the new reference points and determination of good status may vary within the EU. Other member states may want to apply Article 4(5) to deal with climate change impacts due to natural conditions and pressures, in which case the objectives are set at the waterbody level without an institutional support from the Directive or the CIS framework, which is likely to lead to even more heterogenous level of ambition.

Without harmonised methodology or guidance, it is uncertain whether the revisited determinations of good status or objectives set under Article 4(5) will be set at a level compatible with preserving the resilience of aquatic systems to maintain the vital ecosystem services our societies need for adaptation to climate change. Because reviews of the WFD are unlikely after the fitness check declaring the Directive fit for purpose, enhancing the climate resilience of water management law could be improved with efforts in implementation and guidance, such as developing EU-level guidance on adapting the reference conditions and setting less stringent environmental objectives that take into account the inevitable climate change impacts but, nevertheless, pursue maximum ecological sustainability.

Funding: This research received funding from the Strategic Research Council of Academy of Finland (Contract No. 312650 BlueAdapt).

Institutional Review Board Statement: Not applicable.

Informed Consent Statement: Not applicable.

Data Availability Statement: Data sharing not applicable.

Acknowledgments: The author is thankful to the anonymous reviewers and to her PhD supervisors, Antti Belinskij of the University of Eastern Finland Department of Law and the Freshwater Centre of the Finnish Environmental Institute and Niko Soininen of the University of Eastern Finland Department of Law for their helpful comments on previous drafts of this article. However, the author takes full responsibility for any errors or omissions made.

Conflicts of Interest: The authors declare no conflict of interest. The funder had no role in the design of the study, in the writing of the manuscript, or in the decision to publish the results.

\section{References}

1. United Nations Environment Programme (UNEP). Emissions Gap Report 2019. Available online: https:/ /www.unenvironment. org/resources/emissions-gap-report-2018 (accessed on 18 June 2020).

2. The Intergovernmental Panel on Climate Change (the IPCC) Special Report 'Global Warming of $1.5^{\circ} \mathrm{C}^{\prime}$, Adopted at the 48 th IPCC Session on 6 October 2018. Summary for Policy-Makers. Available online: https://www.ipcc.ch/sr15/chapter/spm/ (accessed on 18 June 2020).

3. World Meteorological Organisation (WMO). Provisional Report on the State of the Global Climate 2020. Available online: https:/ / public.wmo.int/en/our-mandate/climate/wmo-statement-state-of-global-climate (accessed on 9 December 2020).

4. Wigley, T.M.L. The Climate Change Commitment. Science 2005, 307, 1766-1769. [CrossRef]

5. Solomon, S.; Plattner, G.K.; Knutti, R.; Friedlingstein, P. Irreversible Climate Change Due to Carbon Dioxide Emissions. Proc. Natl. Acad. Sci. USA 2009, 106, 1704-1709. [CrossRef] [PubMed]

6. Pachauri, R.K.; Reisinger, A. (Eds.) Climate Change 2007: Synthesis Report. Contribution of Working Groups I, II and III to the Fourth Assessment Report of the Intergovernmental Panel on Climate Change; IPCC: Geneva, Switzerland, 2007; p. 104.

7. Jiménez Cisneros, B.E. Freshwater Resources. In Climate Change 2014: Impacts, Adaptation, and Vulnerability. Part A: Global and Sectoral Aspects. Contribution of Working Group to the Fifth Assessment Report of the Intergovernmental Panel on Climate Change; Field, C.B., Barros, V.R., Eds.; Cambridge University Press: New York, NY, USA, 2014. 
8. European Environmental Agency. The European Environment-State and Outlook 2020. Knowledge for Transition to a Sustainable Europe; European Environment Agency: Copenhagen, Denmark, 2019.

9. UN World Water Assessment Programme. The United Nations World Water Development Report 2020: Water and Climate Change. Available online: https:/ / www.unwater.org/publications/world-water-development-report-2020 (accessed on 15 July 2020 ).

10. European Environmental Agency. European Waters-Assessment of Status and Pressures 2018. EEA Report No 7/2018; European Environment Agency: Copenhagen, Denmark, 2018.

11. The European Parliament and the Council of the European Union. Report from the Commission to the European Parliament and the Council on the implementation of the Water Framework Directive (2000/60/EC) and the Floods Directive (2007/60/EC) Second River Basin Management Plans First Flood Risk Management Plans COM(2019) 95 final. Off. J. Eur. Union 2007, 288, 27-34.

12. Directorate-General for Environment. Commission Staff Working Document: European Overview-River Basin Management Plans Accompanying the Document Report from the Commission to the European Parliament and the Council-Implementation of the Water Framework Directive (2000/60/EC) and the Floods Directive (2007/60/EC) Second River Basin Management Plans First Flood Risk Management Plans; SWD(2019) 30 final; European Comission: Brussels, Belgium, 2019.

13. Wilby, R.L.; Orr, H.G.; Hedger, M.; Forrow, D.; Blackmore, M. Risks posed by climate change to the delivery of Water Framework Directive objectives in the UK. Environ. Int. 2006, 32, 1043-1055. [CrossRef] [PubMed]

14. European Commission. The Common Implementation Strategy for the Water Framework Directive and Floods Directive (CIS), Guidance Document No 24: River Basin Management in a Changing Climate; European Commission: Brussels, Belgium, 2009.

15. European Environmental Agency. Climate Change, Impacts and Vulnerability in Europe 2016-An Indicator-Based Report. EEA Report 1/2017; European Environmental Agency: Copenhagen, Denmark, 2017.

16. Willis, K.; Bhagwat, S. Biodiversity and Climate Change. Science 2009, 326, 806-807. [CrossRef] [PubMed]

17. Heller, N.; Zavaleta, E. Biodiversity Management in the Face of Climate Change: A Review of 22 Years of Recommendations. Biol. Conserv. 2009, 142, 14-32. [CrossRef]

18. Robbins, K. The Biodiversity Paradigm Shift: Adapting the Endangered Species Act to Climate Change. Fordham Environ. Law Rev. 2015, 27, 57-105.

19. The United Nations World Water Development Report 2018: Nature-Based Solutions for Water. Available online: https: / / www.unwater.org/publications / world-water-development-report-2018/ (accessed on 15 July 2020).

20. European Commission. Commission Staff Working Document Climate Change and Water, Coasts and Marine Issues; SEC(2009) 386; European Commission: Brussels, Belgium, 2009.

21. Holling, C.S. Resilience and Stability of Ecological Systems. Ann. Rev. Ecol. Syst. 1973, 4, 1-23. [CrossRef]

22. Folke, C.; Carpenter, S.; Walker, B.; Scheffer, M.; Elmqvist, T.; Gunderson, L.; Holling, C.S. Regime shifts, resilience, and biodiversity in ecosystem management. Ann. Rev. Ecol. Syst. 2004, 35, 557-581. [CrossRef]

23. European Commission. Communication from the Commission to the European Parliament, the Council, the European Economic and Social Committee and the Committee of Regions: An EU Strategy on Adaptation to Climate Change. COM (2013) 216. In 2020, the Commission Launched a Public Consultation on the Blueprint for new EU Adaptation Strategy as Part of the EU Green Deal, Intended to be Adopted in 2021. European Commission, Adaptation to Climate Change Blueprint for a New, More Ambitious EU Strategy. Available online: https:/ /ec.europa.eu/info/law/better-regulation/have-your-say/initiatives/12381EU-Strategy-on-Adaptation-to-Climate-Change/public-consultation (accessed on 9 December 2020).

24. Chaffin, B.C.; Garmestani, A.S.; Gunderson, L.H.; Benson, M.H.; Angeler, D.G.; Arnold, C.A.; Cosens, B.; Craig, K.R.; Ruhl, J.B.; Allen, C.R. Transformative environmental governance. Annu. Rev. Environ. Resour. 2016, 41, 399-423. [CrossRef]

25. Arnold, C.A.; Gunderson, L.H. Adaptive Law and Resilience. Environ. Law Report 2013, 43, 10426.

26. Ebbesson, J.; Hey, E. Introduction: Where in law is social-ecological resilience? Ecol. Soc. 2013, 18, 4. [CrossRef]

27. Green, O.O.; Garmestani, A.S.; Allen, C.R.; Gunderson, L.H.; Ruhl, J.B.; Arnold, C.A.; Graham, N.A.J.; Cosens, B.; Angeler, D.G.; Chaffin, B.C.; et al. Barriers and bridges to the integration of social-ecological resilience and law. Front. Ecol. Environ. 2015, 13, 332-337. [CrossRef]

28. Wenta, J.; McDonald, J.; McGee, J. Enhancing Resilience and Justice in Climate Adaptation Laws. Transnatl. Environ. Law 2018, 8, 89-118. [CrossRef]

29. Garmestani, A.; Ruhl, J.B.; Chaffin, B.C.; Craig, R.K.; Van Rijswick, H.F.M.W.; Angeler, D.G.; Folke, C.; Gunderson, L.; Twidwell, D.; Allen, C.R. Untapped capacity for resilience in environmental law. Proc. Natl. Acad. Sci. USA 2019, 116, 19899-19904. [CrossRef] [PubMed]

30. European Commission. Communication from the Commission to the European Parliament and the Council-Addressing the Challenge of Water Scarcity and droughts in the European Union; SEC(2007) 993\} \{SEC(2007) 996; European Commission: Brussels, Belgium, 2007.

31. Doremus, H. Adapting to Climate Change with Law that Bends without Breaking. San Diego J. Clim. Energy Law 2010, 2, 45. [CrossRef]

32. Ruhl, J.B. Climate change adaptation and the structural transformation of environmental law. Environ. Law 2010, 40, 363-431.

33. Craig, R.K. Stationarity is Dead-Long Live Transformation: Five Principles for Climate Change Adaptation Law. Harv. Environ. Law Rev. 2010, 34, 9.

34. Ruhl, J.B. General Design Principles for Resilience and Adaptive Capacity in Legal Systems-With Applications to Climate Change Adaptation. N. Carol. Law Rev. 2011, 89, 1373-1403. 
35. McDonald, J. The role of law in adapting to climate change. Wiley Interdiscip. Rev. Clim. Chang. 2011, 2, 283-295. [CrossRef]

36. Craig, R.K.; Garmestani, A.; Allen, C.R.; Arnold, C.A.; Birge, H.E.; DeCaro, D.A.; Fremier, A.K.; Gosnell, H.; Schlager, E. Balancing stability and flexibility in adaptive governance: An analysis of tools available in U.S. environmental law. Ecol. Soc. 2017, 22, 1-3. [CrossRef] [PubMed]

37. Keessen, A.; van Rijswick, M. Adaptation to Climate Change in European Water Law and Policy. Utrecht Law Rev. 2012, 8, 38. [CrossRef]

38. Holling, C.S. (Ed.) Adaptive Environmental Assessment and Management; Wiley: Hoboken, NJ, USA, 1978.

39. Bruch, C. Adaptive Water Management: Strengthening Laws and Institutions to Cope with Uncertainty. In Water Management in 2020 and Beyond; Biswas, A.K., Ed.; Springer: Berlin/Heidelberg, Germany, 2009; pp. 91-92.

40. Arnold, C.A. Adaptive Watershed Planning and Climate Change. Environ. Energy Law Policy J. 2010, 5, 417.

41. McDonald, J.; Styles, M.C. Legal Strategies for Adaptive Management under Climate Change. J. Environ. Law 2014, 26, 25. [CrossRef]

42. Allen, C.R.; Fontaine, J.J.; Pope, K.L.; Garmestani, A.S. Adaptive Management for a Turbulent Future. J. Environ. Manag. 2011, 92, 1339-1345. [CrossRef]

43. Quevauviller, P. Adapting to climate change: Reducing water-related risks in Europe-EU policy and research considerations. Environ. Sci. Policy 2011, 14, 722-729. [CrossRef]

44. European Commission. Commission Staff Working Document: Fitness Check of the Water Framework Directive, Groundwater Directive, Environmental Quality Standards Directive and Floods Directive; SWD(2019) 439 final; European Commission: Brussels, Belgium, 2019.

45. CJEU Case C-32/05 Commission v Luxembourg [2006] EU:C:2006:749.

46. CJEU Case C-525/12 Commission v Germany [2014] EU:C:2014:2202.

47. Keessen, A.; Van Kempen, J.J.; Van Rijswick, M.; Robbe, J.; Backes, C.W. European River Basin Districts: Are They Swimming in the Same Implementation Pool? J. Environ. Law 2010, 22, 197-221. [CrossRef]

48. CJEU Case C-461/13 Bund für Umwelt und Naturschutz Deutschland, [2015] ECLI:EU:C:2015:433.

49. CJEU Case C-535/18 Land Nordrhein-Westfalen, [2020] ECLI:EU:C:2020:391.

50. CJEU Case C-664/15 Protect Natur-, Arten- und Landschaftsschutz Umweltorganisation, [2017] ECLI:EU:C:2017:987.

51. Van Kempen, J.J. Countering the Obscurity of Obligations in European Environmental Law: An Analysis of Article 4 of the European Water Framework Directive. J. Environ. Law 2012, 24, 499-533. [CrossRef]

52. Howarth, W. The Progression Towards Ecological Quality Standards. J. Environ. Law 2005, 18, 3-35. [CrossRef]

53. van Holten, S.; van Rijswick, M. The Governance Approach in European Union Environmental Directives and Its Conse-Quences for Flexibility, Effectiveness and Legitimacy. In EU Environmental Legislation-Legal Perspectives on Regulatory Strategies; Peeters, M., Uylenburg, R., Eds.; Edward Elgar Publishing: Cheltenham, UK, 2014.

54. Josefsson, H. Ecological Status as a Legal Construct-Determining its Legal and Ecological Meaning. J. Environ. Law 2015, 27, 231-258. [CrossRef]

55. Milly, P.C.D.; Betancourt, J.; Falkenmark, M.; Hirsch, R.M.; Kundzewicz, Z.W.; Lettenmaier, D.P.; Stouffer, R.J. Stationarity is Dead: Whither Water Management? Science 2008, 319, 573. [CrossRef] [PubMed]

56. Dufour, S.; Piégay, H. From the myth of a lost paradise to targeted river restoration: Forget natural references and focus on human benefits. River Res. Appl. 2009, 25, 568-581. [CrossRef]

57. Matthew, D.Z. Adapting to Climate Change: Environmental Law in a Warmer World. Ecol. Law Q. 2007, 34, 61.

58. Arvai, J.; Bridge, G.; Dolsak, N.; Franzese, R.; Koontz, T.; Luginbuhl, A.; Robbins, P.; Richards, K.; Korfmacher, K.S.; Sohngen, B.; et al. Adaptive Management of the Global Climate Problem: Bridging the Gap Between Climate Research and Climate Policy. Clim. Chang. 2006, 78, 217-225. [CrossRef]

59. Foerster, A. Water Law: Adapting to Climate Change in South-Eastern Australia. In Water and the Law: Towards Sustainability; Michael, K., Ed.; Edward Elgar: Cheltenham, UK, 2014.

60. European Commission. Communication from the Commission to the European Parliament, the Council, the European Economic and Social Committee and the Committee of the Regions: Report on the Review of the European Water Scarcity and Droughts Policy; SWD(2012) 380 final; European Commission: Brussels, Belgium, 2012.

61. Bouleau, G.; Pont, D. Did you say reference conditions? Ecological and socio-economic perspectives on the European Water Framework Directive. Environ. Sci. Policy 2015, 47, 32-41. [CrossRef]

62. Carvalho, L.; Mackay, E.B.; Cardoso, A.C.; Baattrup-Pedersen, A.; Birk, S.; Blackstock, K.L.; Borics, G.; Borja, A.; Feld, C.K.; Ferreira, M.T.; et al. Protecting and restoring Europe's waters: An analysis of the future development needs of the Water Framework Directive. Sci. Total Environ. 2019, 658, 1228-1238. [CrossRef]

63. CJEU Case C-43/10 Nomarchiaki, [2012] ECR I-0000.

64. CJEU C-664/14 Commission v. Austria, [2016] ECLI:EU:C:2016:322.

65. Owen, D. Little streams and legal transformations. Utah Law Rev. 2017, 1, 1-55.

66. Spears, B.M.; Ives, S.C.; Angeler, D.G.; Allen, C.R.; Birk, S.; Carvalho, L.; Cavers, S.; Daunt, F.; Morton, R.D.; Pocock, M.J.O.; et al. FORUM: Effective management of ecological resilience-Are we there yet? J. Appl. Ecol. 2015, 52, 1311-1315. [CrossRef] 
67. Richard, J.L. Super Wicked Problems and Climate Change: Restraining the Present to Liberate the Future. Cornell Law Rev. 2009, $94,1153$.

68. Soininen, N.; Platjouw, F.M. Resilience and Adaptive Capacity of Aquatic Environmental Law in the EU: An Evaluation and Comparison of the WFD, MSFD, and MSPD. In The Ecosystem Approach in Ocean Planning and Governance-Perspectives from Europe and Beyond; Langlet, D., Rayfuse, R., Eds.; Brill: Leiden, The Netherlands, 2018. 